\title{
The Freedom of Religion - Religious Harmony Premise in Society $\mathrm{PhD}$ Candidate Oljana Hoxhaj
}

\author{
University of "Isamil Qemali" Vlora, Faculty of Human Sciences, Department of Law \\ oljana.hoxhaj@gmail.com
}

\section{Doi:10.5901/ajis.2014.v3n6p193}

\section{Abstract}

Albania is considered as a state characterized by religious coexistence. The freedom of religion is considered as one of the essential elements in any society with democratic values. This freedom can be implemented individually or collectively. Depending on the degree of emancipation of the state, the latter creates the premise that the individual freely to choose his religion, and have no obstacle to display it. The purpose of this paper is to address religious freedom as a constitutional affirmation and also as a freedom sanctioned in a number of international acts, for the importance and the impact of religion on consolidating human personality and the whole society.A particular importance is given to the analysis of the practice of the European Court of Human Rights, not omitting even the case in a public school in Albania, where legal discussion, focuses on legitimation or not of the management authorities to stop the attendance of learning of both under-age girls because they wore headscarves.Part of the paper is the relationship between religion and state that these links coexist peacefully and operate in harmony.

Keywords: The freedom of religion, manifestation, harmony, headscarf, constitution, international legislation

\section{Introduction}

The freedom of religion deals with an important issue for human society. Historically humanity has exercised beliefs and convictions as well as is not hindered by the state to enjoy them. Even claimed that the theory of human rights is based on the long history of the existence and protection of religious beliefs. The freedom of religion has to do with the individual search on the truth and meaning of life.This type of activity is an activity related more to human consciousness and the desire to see the world through the individual eye and as the individual perceives himself, based on his intelligence or the knowledge that possess.As such, this right is closely related to all aspects of human development.

This article concerns a matter which is not in itself problematic and, in fact, for it, there were not many complaints to the Committee of Human Rights at the United Nations. The problem with this freedom begins when to individuals, imposed a particular belief, when the legal system of a country imposes a general and uniform rate, in relation to the issue of trust. So the real problem about this right has nothing to do with the substance the right as such, the internal mental state and the creation of a particular trust, but when displayed, when expressed, and when we think should be expressed in interaction with others this right. The freedom of belief, religion is a right which can not be considered accomplished if no guaranteed the freedom of expression \& organization. ( Sinani , Dhamo, Hysi , Kamani , Methasani , Harasani, 2008)

Free exercise of religion is similar and closely related to other freedoms listed in the catalog of fundamental rights and freedoms. Most prominent are freedom of expression, the right to be organized, freedom of demonstration and the right to education. Through the respect to these rights, achieved to appear the religious convictions in public, to be carried out the religious services, prayer, liturgies, to rejoice freely their right to education, etc... Article 24 of the Albanian Constitution is undoubtedly the classic article of religious freedom in our constitution, accompanied by a number of other articles, which serve as guarantee to achieve this freedom. Firstly, the religious coexistence, which has always been present in the Albanian tradition, it is affirmed alongside several other essential principles. (Omari, Anastasi , 2008, $p$ 134)

In the preamble of the Constitution, the affirmation is presented as a core component of the creation of the state and society : "with the spirit of tolerance and religious coexistence." To give due importance to this freedom, the legislator has reasonably estimated that, besides the affirmation in the declarative part of the Constitution, to grant a full sanctioning in the normative part of the Constitution. I think that this is necessary for each society because it creates all the prerequisites to guarantee social and religious coexistence. Albanian Constitution has expressed this clearly: "The independence of the state and integrity of its territory, human dignity, rights and freedoms, social justice, constitutional 
order, pluralism, national identity and heritage, religious coexistence as well as coexistence and understanding of the Albanian minorities are the bases of this state, which has the duty to respect and protect them." (Article 3 of the Constitution of the Republic of Albania)

\section{The Freedom of Religion and Its Sanctioning in Albanian and International Legislation}

The freedom of religion is affirmed in the Constitution of the Republic of Albania and consists in the right, which is granted to every citizen to choose his religion and to manifest his religious beliefs, individually or collectively. The Constitution protects both freedom as freedom of religion, including the free exercise of religious worship, as well as the freedom not to choose the religious faith or not to choose any cult, as well as the freedom not to be believer.Free exercise of religion means freedom to practice a certain religion. Albanian Constitution provides that:

1. Freedom of conscience and religionis guaranteed.

2. Everyone is free to choose or change their religion or beliefs, as well as to express them individually or collectively, in public or private life, between cult, education, practices or rituals application.

3. Nobody may be compelled or prohibited to take part in a religious community or its practices, and to make public his beliefs or faith. (Article 24 of the Constitution of the Republic of Albania)

The freedom of religion not only provided as a general collective right, but as an individual right for every person. The sanctioning of this freedom in the highest legal act of the state, has a pronounced approach to treatment that makes the Universal Declaration. Specifically, in the content of this statement is provided that:

"Everyone has the right to freedom of thought, conscience and religion. This right includes freedom to change his religion or belief, and the freedom of individual, either himself or in community with others, to display, publicly or privately, his religion or belief through teaching, application of worship and religious ceremonies." (Article 18 of the Universal Declaration of Human Rights)

Parallel to the above sanctions, operates also the European Convention. Embodied in Article 9, freedom of thought, conscience and religion is one of the foundations of a democratic society within the meaning of the Convention. In its religious dimension, is not only one of the most vital elements that make up the identity of believers and their conception of life, but is also an invaluable asset for atheists, skeptics and non-interested.

At the convention this freedom is sanctioned as follows:

1. Everyone has the right to freedom of thought, conscience and religion; this right includes freedom to change his religion or belief and freedom to manifest his religion or his beliefs individually or collectively, in public or private, through worship, teaching, practice and rituals application.

2. Freedom to manifest one's religion or beliefs shall not be subject to other restrictions other than those prescribed by law and are necessary measures for a democratic society for public safety or for the protection of public order, health or morals or for the protection of the rights and freedoms of other people. (Article 9 of the European Convention on Human Rights)

\subsection{International acts that guarantee the freedom of religion}

Besides legal instruments cited above, are also other international acts that guarantee the freedom of religion in relation to other rights, which complement each other and ensure all the necessary facilities to any person to exercise effectively the freedom of religion. Such are considered:

- International Covenant on Civil and Political Rights, Article 18. The right to religion, belief and conscience is guaranteed in an article with the same number as that of the statement in the Universal Human Rights, but Article 18 includes not only the content of Article 18 of the UDHR, but also the content of Article 26 (3) of the UDHR as well as Article 2.

- International Convention on the Elimination of All Forms of Racial Discrimination: Article 5.

- UNESCO Convention against Discrimination in Education: prohibits discrimination based on religion and political thought, or other: Article 1 as well as Article 5.

- Convention of the International Labour Organization no. 11: Article 1 prohibits discrimination in employment relations on the basis of religion.

- Declaration on the Elimination of All Forms of Intolerance and of Discrimination Based on Religion or Faith.

- Convention on the Rights of Children: Article 14. 
- ECHR: Article 9 (1) and its Protocol 19 (3).

\section{The Relationship between State and Religion, Cases from the Practice of the European Court of Human Rights}

Among the biggest differences regarding the protection of religious freedom in the world, dealing with relations between states and religions or beliefs. We have several principal patterns of state and religion: religious states, established churches, state neutrality towards religions and other institutions, non-existence of any official religion, separation of church and state and the protection of religious groups recognized by law. International standards do not require separation of state and church or religion. This means that, is not appointed any particular model of relationship between state and beliefs, and in particular does not require the creation of secular societies, which exclude religion from public affairs.

The only international requirement is that such a relationship should not result in discrimination against those who do not belong to recognized official religion, or religions recognized by law. However, where only one religion is an integral part of national identity, it is questionable if we can ensure equal treatment of other religions or smaller religions. According to Western views, a neutral relationship between religion and state makes more possible the guaranteeing of complete protection of religious freedoms of individuals. (European Centre for Training and Research for Human Rights and Democracy (ETC), 2003) Another important issue to be addressed in this context consists of state intervention in the internal affairs of religious institutions. In recent years, the European Court has found a violation of Article 9, in cases where states have intervened in the organization or internal affairs of religious groups.

This is evidenced in several cases in Greece ( Case: Serif against Greece, 1999), where the applicants had been convicted of the offense of "usurpation of the functions of a minister who belonged to a religious faith known for his religious dress in public. Applicants in these cases were selected as mufti in their communities, while the government had appointed other persons in the same functions. In finding violations of Article 9, the Court ruled that the conviction of a religious leader, when a group of individuals of their own volition follow him as such, is incompatible with the requirements of a religious pluralism in a democratic society. The court also noted that in a democratic society can not be seen as necessary for the state to take measures to ensure that religious communities have a common leadership.

Although the Court recognizes that it is possible to create tension in situations where a religious community or another community is divided, stating that this is one of the inevitable consequences of pluralism. The role of the authorities in such circumstances should not eliminate the cause of tension by eliminating pluralism, but to ensure that the competing groups tolerate each other. (Case: Agga against Greece, 2002)

Similar facts came out, even when the government had intervened in the organization and leadership of the Muslim communities in Bulgaria, refusing to do, the registration of some decisions taken at a national conference of Muslims and the changes made in the internal statute, of group, registerering a rival group as the only organization representing the religious belief in Bulgaria, allowing rival group forcibly evict the applicants from their offices under the authority of that registration.

The Court held that religious communities generally exist in the form of organized structures. They obey some rules that often are considered from the followers of a divine origin. If directed by Ministers authorized for that purpose, in accordance with these rules, religious ceremonies have their sacred meaning and value to believers. Personality of religious ministers is undoubtedly important for every member of the community. Participation in community life is a manifestation of religious belief protected by Article 9 of the Convention. (Gomien, 2005, p 96-97)

Freedom of thought, conscience and religion, is ranked as an essential element of the identity of believers and their concept to life. In particular, freedom of religion means manifestation of religion, not only collectively but also individually. In its jurisprudence, the European Court has not specified whether the headscarf holding constitutes a permanent or non-fulfillment of a religious obligation. She says that this act is inspired by a religion or belief. (Case: Sahin against Turkey, 29 June 2004) The European Court concluded that the attitudes of the authorities do not allow wearing headscarves in academic environments constitutes an interference against the exercise of the right to manifest his religion. (Case: Kokkinakis against Greece, 25 May 1993)

In another case, the European Court reasoned that:

"The right to freedom of thought, conscience and religion is an absolute right, and can not be restricted. What may be limited, it is only the right to display or practice religion or belief." (Case: Metropolitans of Basarab and others against Moldova, 13 December 2001) 


\section{Headscarf - Manifestation of Religious Belief in School and Legal Problems}

In March 2008, a story given to the media, concerning two young girls, 11 and 13 years, who were forbidden to attend school because they wore headscarves, sparked a legal debate in Albania. The Direction Authorities of the school, 9years girls do not allowed them to continue lessons, because as practitioners of the Muslim faith, wore headscarves during the learning process. This action is considered illegal, as was contrary to law "For the Secondary Education" and the internal regulation of the school. (Centre for Parliamentary Studies, 4/2008 p 69-70) The Direction Authorities argued that the participation of girls in the educational process with headscarf contradicts the sanctioning: "Public pre- university education is secular. In public educational institutions prohibited religious indoctrination." (Law no.7952, dated 21.06.1995 "On Secondary Education")

At the same time it contradicts with the internal regulation of the school, which provides that: "The student must have regular external appearance and without makeup, with white shirts and pants."If we analyze the case, I thought that the school direction authorities have taken a wrong decision, which has led to the violation of the right of girls to manifest their faith freely. So we have violation of freedom affirmed in the constitution, in Article 24 and in Article 9 of the ECHR. Albanian legislation has integrated it into internal European Convention system, consequently this means that:

"Limitations of the rights and freedoms provided for in the Constitution may be imposed only by law in the public interest or for the protection of the rights of others. These limitations may not infringe the essence of freedoms and rights, and in any case can not exceed the limitations provided for in the ECHR". (Article 17 of the Constitution of the Republic of Albania)

So, in this context, we highlight a limitation of a constitutional liberty arbitrarily and in excess of the limitations provided for in the ECHR. I think it is imperative that this issue and other similar, legally be analyzed taking as reference the rich practice of the European Court. Through them we have the necessary gaps to raise standards of respect for freedoms enshrined in the Constitution. Overall, the general spirit of the European Convention and the Strasbourg jurisprudence, consider the use of the headscarf as a "practice" that manifests religious affiliation or a particular faith, as well as the act of expression and communication of ideas, so enters into the area of implementing the European guarantees of religious freedom and freedom of expression.

\section{Conclusions}

At the conclusion of this paper, it is necessary to emphasize that freedom of religion is one of the most important mechanisms through which individuals can perceive, manifest and display beliefs, thoughts and ideas. This freedom is regarded as closely related to the principle of human dignity, but also with space for a person to participate in a religious community and its practices. The fact that freedom of religion sanctioned at the highest act of the state, but also in other international acts emphasizes the link that the individual has close to religion, but also the need that his worldview about religion not affected by the legislation. Despite affirming legal developments in a dynamic society, can not observed problems and conflicting attitudes of different groups in relation to specific religions. In this context, it should highlight the role of the state, which has all the skills, by practicing proper policies, and non-discriminatories, in order to harmonize the activities of religious institutions and to stimulate religious coexistence.

However, in Albanian society has had discussions about forms of manifestation of faith, especially in public schools. I think the stage of emancipation of the state and our society should be measured by the ability that the latter have to give the example that religious conflicts prevented relying highest democratic values as solidarity, respect of diversity, justice and the spirit of tolerance.Albania is recognized internationally as a country characterized by religious coexistence. I believe that the reasons of this religious harmony, are associated with maintaining the balance between influence and state intervention in the internal activity of religious institutions and also with the fact that our state is based to the principle of secularism and equality. These create all the conditions that believers feel equally protected and religious institutions feel more independent in their activities.

\section{References}

Constitution of the Republic of Albania

Sinani M, Dhamo M, Hysi V, Kamani P, Methasani E, Harasani Zh (2008) "Commentary, of Universal Declaration of Human Rights" Omari L, Anastasi A, (2008), "Constitutional Right", ABC, Tirana 
Universal Declaration of Human Rights

European Convention on Human Rights

European Centre for Training and Research for Human Rights and Democracy (ETC), (2003) "Understanding Human Rights" MANZ CROSSMEDIA, Vienna, Austria.

Serif against Greece (1999)

Agga against Greece (2002)

Gomien D, (2005) "Short Guide to the European Convention on Human Rights" Gentgrafik, Tirana

Sahin against Turkey, (29 June 2004)

Kokkinakis against Greece, (25 May 1993)

Metropolitans of Basarab and others against Moldova (13 December 2001).

Magazine "Parliamentary Law and Legal Policy," (4/2008), a publication of the Centre for Parliamentary Studies

Law no. 7952, dated 21.06.1995 "On Secondary Education"

International Covenant on Civil and Political Rights

International Convention on the Elimination of All Forms of Racial Discrimination

Convention against Discrimination in Education: prohibits discrimination based on religion and political thought

Convention of the International Labour Organization no. 11

Declaration on the Elimination of All Forms of Intolerance and of Discrimination Based on Religion or Faith

Convention on the Rights of Children

http://mdhamo.files.wordpress.com/2010/01/unesco.pdf

http://www.etcgraz.at/typo3/fileadmin/user_upload/ETCHauptseite/manual/versionen/albanian/relig/relig.pdf 
